a modern knowledge-based society. Thus, they need to learn new skills needed to communicate effectively in English, which enables them to compete on the world stage and deal with the demands of globalization. This means that EFL classes need new types of teaching methods for new types of students, and that means creating an active student-centered class. Students need interesting, current, authentic and relevant lesson content, and teachers who stimulate their curiosity and encourage them to ask questions, express their own ideas and views and begin to think critically.

Indeed, at the recent Davos Economic Forum on the future of work, a session leader stated, "When adults practice what they have learned, retention and ownership of the content increases significantly. In a corporate environment, this is the holy grail of learning - encouraging people to own, retain and apply what they have learned" [6]. The session participants listed the top work skills in demand for the 2020s as critical thinking, active learning, and creativity [7].

Ms. Irgaliyeva and Dr. Bantel worked very hard to help their students not only become more fluent speakers but also to become active and independent learners with the valuable skills they need for the future.

\title{
References:
}

1. Chomsky, N. Aspects of the theory of syntax. Cambridge // MIT Press. - 1965.- magazine article

2. Hymes, D. H. On communicative competence // In: J.B. Pride and J. Holmes (eds.) Sociolinguistics: Selected readings Harmondsworth, UK: Penguin. - 1972.- p. 269-293.- magazine article

3. Canale, M. \& Swain, M. Theoretical bases of communicative approaches to second language teaching and testing. //Applied Linguistics, 1(1). - 1980. - p.1-47. - magazine article

4. Nunan, D. Language teaching methodology: A textbook for teachers. London: Prentice Hall. 1991.- book

5. Education policy outlook for Kazakhstan. - December, 2018. - Retrieved from

https://www.oecd.org/education/Education-Policy-Outlook-Country-Profile-internet source

6. Gray, A. The ten skills you will need to survive in the fourth industrial Revolution. - January, 2019. Retrieved from https://www.weforum.org/agenda/- - internet source

7. Kang, S.-Y. To build the workforce of the future, we need to revolutionize how we learn. September, 2019. - Retrieved from https://www.weforum.org/agenda/2019/09/- internet source

МРНТИ 14.35.07

https://doi.org/10.51889/2020-1.1728-5496.22

\author{
D. K. Raikhanoval , G.M. Kassymova ${ }^{2}$ \\ ${ }^{1,2}$ Suleyman Demirel University \\ Kaskelen, Kazakhstan
}

\section{FORMATION OF PROFESSIONALLY-ORIENTED COMPETENCE IN TEACHING ENGLISH FOR ACADEMIC PURPOSES FOR CHEMISTRY - BIOLOGY STUDENTS}

English for Specific Purposes (ESP) is categorized into two main classification areas English for Academic Purposes (EAP) and English for Occupational Purposes (EOP). In this article authors briefly describe the differences between these two sub-branches of ESP. At the same time this article deals with the implementing English for Academic Purposes (EAP) in teaching Combined Major Program 6B015002 'Chemistry and Biology' at Suleyman Demirel University (SDU). Some of higher-leveled students like to enhance their comprehension of Academic English. Thus, EAP course was introduced to meet higher-leveled students' academic and professional interests. The main purpose of the EAP course was to provide learners with all basic abilities to conduct research and generate a piece of extended writing in their own subjectspecific area. Students not only needed to work on their study skills such as techniques, note-taking, and compiling bibliography, but also on acquiring study competencies which involved development of critical questioning, allocating the tasks, compiling an abstract book, and organizing conference skills.

Key words: English for Specific Purposes (ESP), English for Academic Purposes (EAP), chemistry and biology students, compiling abstract book, and organizing lesson - conference 


\author{
Д. К. Райханова ${ }^{1}$, Г. М. Касымова ${ }^{2}$ \\ ${ }^{1,2}$ Сулейман Демирел Университет \\ Қаскелен, Қазақстан
}

\title{
«ХИМИЯ-БИОЛОГИЯ» МАМАНДЫҒЫ СТУДЕНТТЕРІНІН АКАДЕМИЯЛЫҚ МАҚСАТТАРҒА АРНАЛҒАН АҒЫЛШЫН ТІЛІН ОҚЫТУ БАРЫСЫНДА КӘСІБІ БАҒЫТТАЛГАН ҚҰЗІРЕТТІЛІКТЕРІН ҚАЛЫПТАСТЫРУ
}

\begin{abstract}
Анъдатпа
Арнайы мақсаттарға арналған ағылшын тілі Академиялық мақсаттарға және Кәсіби мақсаттарға арналған ағылшын тілі деп негізгі екі классификацияға бөлінеді. Мақаланың авторлары арнайы мақсаттарға арналған ағылшын тілінің осы екі тармақтың арасындағы айырмашылықтарды қысқаша сипаттайды. Сонымен қатар бұл мақалада Сулейман Демирел Университетінің (СДУ) 6В015002 химия / биология мамандығына бағытталған академиялық мақсаттарға арналған ағылшын тілі курсын оқыту тәжірибесі қарастырылған. Академиялық мақсаттарға арналған ағылшын тілі курсының негізгі мақсаты студенттерге өз мамандықтарына сай тақырып таңдап, зерттеу жүргізіп, кеңейтілген ғылыми жазба жұмысын жүргізе отырып, құзыреттіліктерін дамыту.

Түйін сөздер: Арнайы мақсаттарға арналған ағылшын тілі, академиялық мақсаттарға арналған ағылшын тілі, кәсіби бағытталған құзіреттілік, химия, биология, аңдатпа жинағын құрастыру, конференция ұйымдастыру.

\author{
Д. К. Райханова ${ }^{1}$, Г. М. Касымова ${ }^{2}$ \\ ${ }^{1,2}$ Университета имени Сулеймана Демиреля
} Каскелен, Казахстан

\section{ФОРМИРОВАНИЕ ПРОФЕССИОНАЛЬНО-ОРИЕНТИРОВАННОЙ КОМПЕТЕНЦИИ В ПРЕПОДАВАНИИ АКАДЕМИЧЕСКОГО АНГЛИЙСКОГО ЯЗЫКА У СТУДЕНТОВ СПЕЦИАЛЬНОСТИ «ХИМИЯ-БИОЛОГИЯ»}

\begin{abstract}
Аннотация
Английский язык для специальных целей подразделяется на две основные категории: Академический английский язык и профессиональный английский язык. В этой статье авторы кратко описывают разницу между этими двумя подразделами. В то же время эта статья посвящена внедрению английского языка для академических целей в преподавании 6В015002-химии -биологии в Университете Сулеймана Демиреля (СДУ). Студентам с более высоким уровнем английского языка был предложен курс Академический Английский Язык для удовлетворения академических и профессиональных интересов. Основная цель курса Академический Английский Язык состояла в том, чтобы предоставить учащимся все основные возможности для проведения исследований и создания фрагмента расширенного письма в своей профессиональной области. Студент работает не только над своими учебными компетенциями, но также и над овладением учебными навыками, которые вкючили в себя разработку критических вопросов, распределение заданий, составление сборника аннотаций и навык организовывать конференцию.

Ключевые слова: Профессионально-ориентированный английский язык, Академический английский язык, компетенции, химия, биология, сборник аннотаций, организация конференции.

\section{Introduction}

ESP is classified as fixed teaching approaches among English Language Teaching (ELT). It has been known for 50 years of research, use, and it is probably the leading approach in academic environment [1]. ESP is an approach which gets effective, productive, and proper concepts from different theories blending them into an integrated system. It includes some features from Communicative Language Teaching (CLT), Task-Based Language Teaching (TBLT), Project-Based Learning (PBL) [2]. In addition it has its peculiar characteristics such as learner-centeredness, correlation with specialized subjects, and dwell on both designing and educating. Thus, according to Anthony Laurence ESP is
\end{abstract}


English for Specific Purposes (ESP) is an approach to language teaching the target the current and/or future academic or occupational needs of learners, focuses on the necessary language, genres, and skills to address these needs through the use of general and/or discipline-specific teaching materials and methods. [3]

It is time to head deeply particularize acronyms related to ESP like EAP, EOP, EST, and EBP. According to Hutchinson and Waters [4] ESP has two major classification areas English for Academic Purposes (EAP) and English for Occupational Purposes (EOP). Robinson [5] classifies ESP due to experience needs where EAP is for study usage in a specific discipline which involves pre-study, in-study, and post-study stages. In addition it is used as a school subject in independent and integrated ways. Whereas EOP classified as pre-experience, simultaneous or in-service and post-experience stages. It is very useful to divide course into EAP and EOP course subdivisions according to when they occur. These differences are significant since they will influence the course particularities. Pre-experience or pre-study course will possibly exclude specific work which deals to the real study or job since learners still are not acquainted with the content, whereas the specific work is required in the educational institutions or workplace that is parallel to the course of study. The tree diagram shown below for ESP is presented by Dudley Evans and St. Johns $[6$, p. 6] which classifies EAP and EOP due to discipline or professional area.

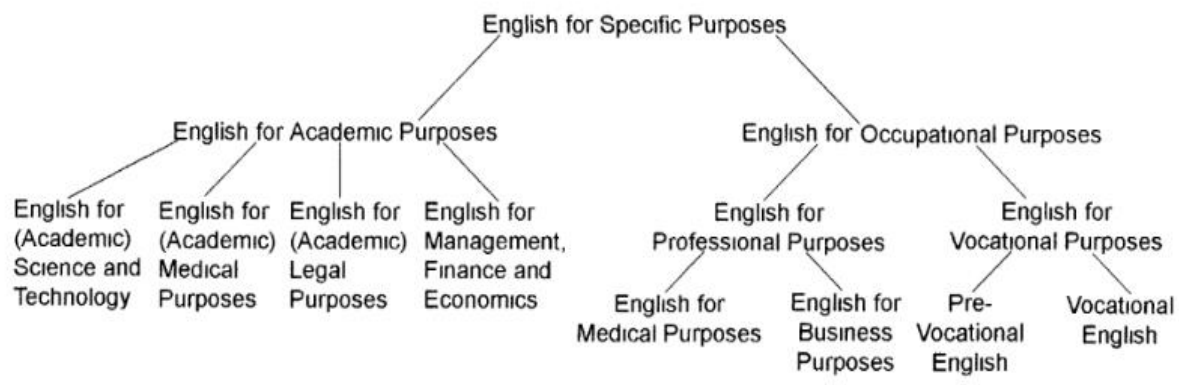

Figure 1 ESP classification by professional area according to Dudley Evans and St. Johns (1998)

Despite the fact that EST is prior area in EAP, both EMP and ELP equally play an important role. The EOP term relates not for academic purposes and it contains professional purposes in medicine, law, and business, whereas vocational purposes for non-professionals in work or pre-work situations. So the language and discourse could be distinguished between those who are studying medicine and those who are already practicing doctors. English for (Academic) Medical Purposes should be designed for students and English for occupational (professional) purposes for practitioners. English for Vocational Purposes (EVP) are divided into two sub-branches as Vocational English that is focused on training language for specific trades or occupations and Pre-Vocational English that is involved in finding a job and interview skills. [6]

\section{Methodology}

Comprehending the English language at higher educational institutions is one of the predominant importances for learners to attain good outcome in learning their subjects through textbooks and lectures [7]. By 'learners' we mean $1^{\text {st }}$ year undergraduate students of 6B015002 'Chemistry and Biology' specialty at Suleyman Demirel University (SDU). The knowledge of English proficiency of chemistry-biology students at SDU in the 2018-2019 academic year fluctuates from elementary, pre-intermediate to intermediate and upper-intermediate/advanced levels according to the Common European Framework. Most of students who showed high level of English graduated Nazarbayev Intellectual Schools (NIS) or Bilim Innovation Lyceum (BIL) where most of science subjects are already conducted in English. Thus, approximately a quarter of those higher- leveled learners experienced insufficient, or almost no modification in their English language improvement in ESP classes. The data of students' goals in taking ESP course has shown that higher- leveled learners anticipate to use English in different ways, not only circumstances in professional field, thus 25\% of learners would like to enhance their comprehension of Academic English or IELTS preparation. Following the reasons mentioned above, it seems that students want ESP course also meets their academic and professional needs respectively. That is why we introduced EAP course for higher leveled students so it can meet their academic and professional interests. The main purpose of the EAP course was to provide learners with all basic abilities to conduct research and generate a piece of extended writing in their own subjectspecific area. In our case learners were able to choose any topics that are interesting for them related to 
chemistry, biology fields itself, or teaching chemistry-biology. The EAP course included combined approach which was focused on writing and research skills. In addition the oral component was presented through students' work discussion in class, in tutorials, and in final conference at the end of the term when students organized the conference session and presented their work. Discrete reading and writing skills were assumed to be taught in components of English for Academic Purposes course, as well as presentation skills. Students dealt with books, articles related to their topics in order to better understand it and complete the extended writing assignment. In given EAP course students learned to choose topics, find some sources, develop drafting and redrafting skills, generate their ideas, and identify the writing purpose. We tried to give students as much autonomy as possible so they could work independently since students are expected to be independent learners in higher education. They not only needed to work on their study skills such as techniques, note-taking, and compiling bibliography, but also on acquiring study competencies which involved development of critical questioning, allocating the tasks, compiling an abstract book, and organizing conference skills. Most of the given tasks were completed for homework, and checked in class.

As it was mentioned above the EAP course for chemistry-biology students was divided into several stages. The first stage consisted of choosing a topic for extended writing, then collecting materials, and reading articles on a selected topic, afterwards compiling all the collected data in the form of literature review. The second stage was working on your methodology part by conducting interviews, questionnaires and final stage was to provide and submit your last piece of writing on the turnitin.com. Turnitin is an American commercial, Internet-based plagiarism detection service website, which checks submitted documents against its database and the content of other websites with the aim of identifying plagiarism. Results can identify similarities with existing sources, help students to avoid plagiarism and improve their writing [8]. According to evaluation criteria the percentage of work similarity should not exceed 30 per cent out of 100. In addition to uploading written work to turnitin, students had to organize a conference on selected and elaborated topics.

\section{Results}

The procedure of organizing and conducting a conference was as follows. Students randomly were divided into 3 teams. The task of the first team was to collect titles and abstracts of upcoming articles and edit them in the form of book of abstracts (see figure 2).
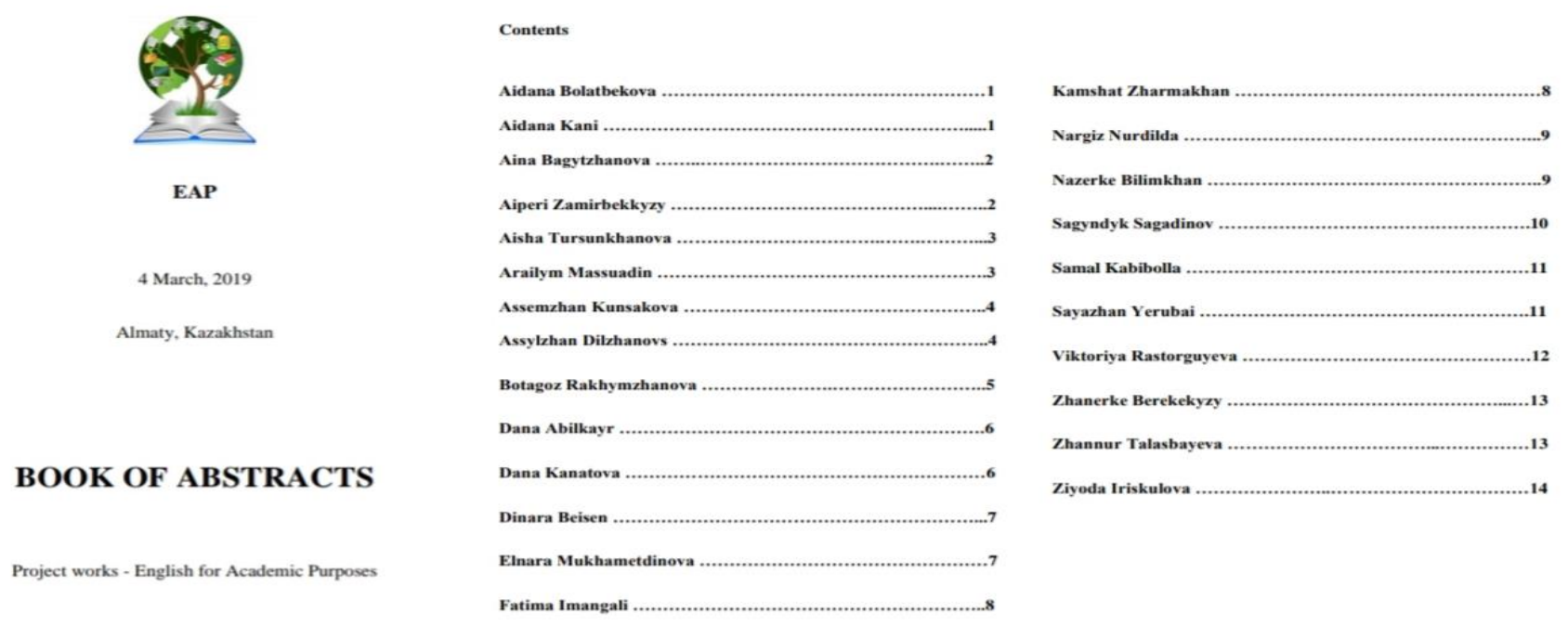
Cognitive behavioral therapy (CBT) is one of the most effective ways to treat disorders and replace traditional medicine. The goal of research is to identify extent of inflence of CBT on our mental health in solving problems. Current problems that are caused by daily load at work. mchoot do not allow us to think future of CBT is to move pernonulined care, which may only be achieved by departing from the psychiatric classification system and the modical model According to the investigation, CBT is one of the necessary things in the modern. dynamic world where problems are solved by using special methodologies.

Key words: cognitive behavioral therapy, disorders, influence of CBT, load. personalized care, methodologies.

$\begin{aligned} & \text { Designing a trilingual magie vocabulary book for the future } \\ & \text { chemistry and biology teachers }\end{aligned}$
Thannur Talasbayeva
B.Sc., Suleyman Demirel University
Kaskelen, Karakhstan

This project will try to solve one of the problems existing in education system. Everybody knows that starting from 2020 in Karakhstan all ordinary schools plan to teach science subjects in English. Nazarbayev Intellectual Schools and Bilin Innovation Lyceums are already teach science in English. Moreover, Nazarbayev working with international teachers Und foreign pcientific book

Unfortunately, according to the results of questionnaire some students who are planning to teach science subject in the future have lack of vocabulary. Analysis was conducted from son $13 \mathrm{w}$ was taken to avoid those difficulties in study/teaching process. By the

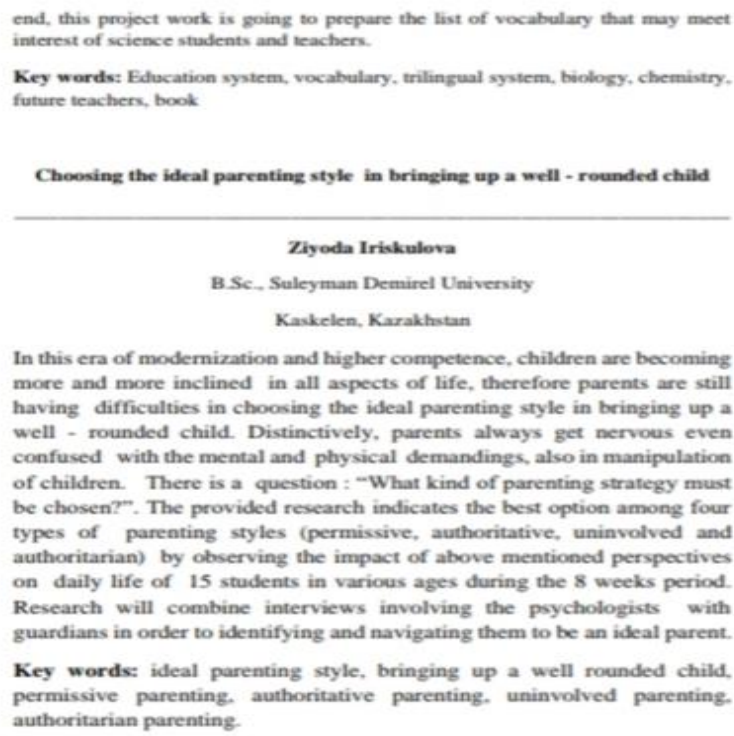

In this era of modernization and higher competence, children are becoming more and more inclined in all aspects of life, therefore parents are still having difficulties in choosing the ideal parenting style in bringing up a well - rounded child. Distinctively. parents always get nervous even confused with the mental and physical demandings, also in manipulation of children. There is a question : "What kind of parenting strategy must be chosen?". The provided research indicates the best option among four be chos of parenting styles (permissive, authoritative. unimolve four types of pareating styles (permissive, authoritative, uninvolved and authoritarian) by is string the impact of above mentioned perspectives Research will combine interviews involving the psychologists with guardians in order to identifying and navigating them to be an ideal parent.

Key words: ideal parenting style, bringing up a well rounded child. permissive parenting, authoritative parenting, uninvolved parenting. authoritarian parenting

Figure 2 Example of Book of Abstract in EAP course

The task of the second team was to make invitation brochures in order to invite as many students and teachers as possible to the lesson-conference (see figure 3 ).

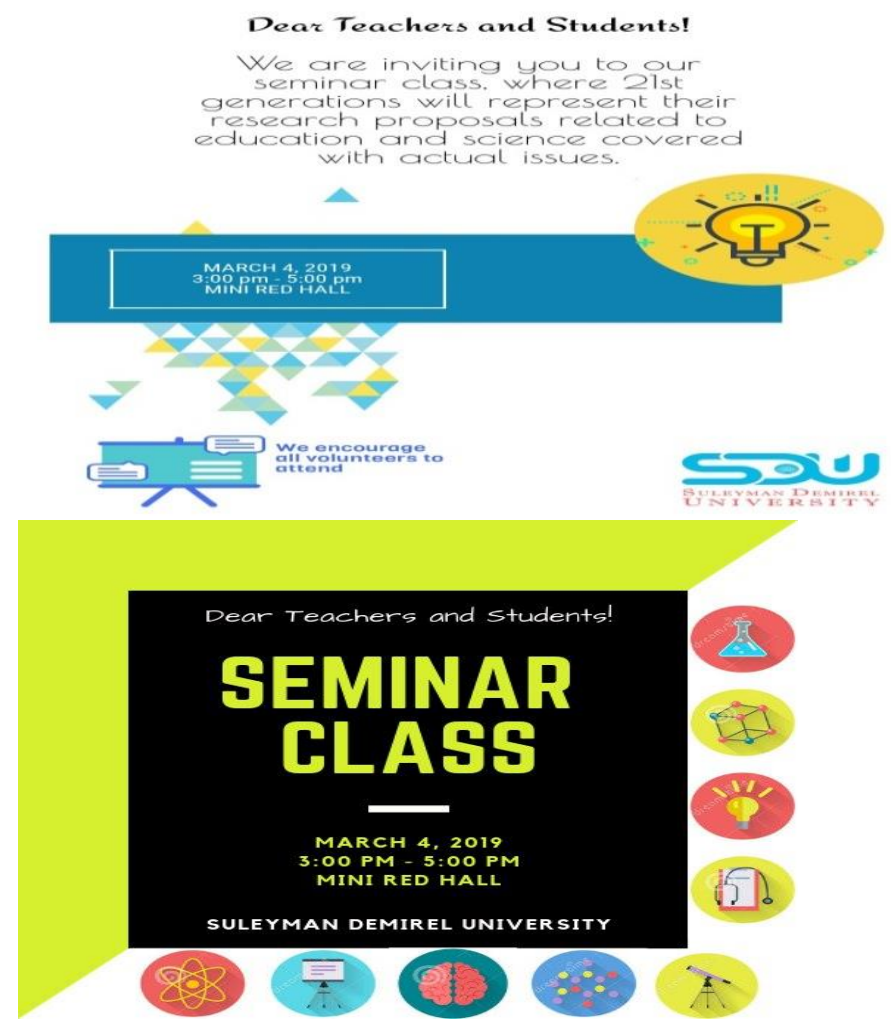

Figure 3 Invitation to Conference in EAP course

The task the last third team was to collect all the presentations according to the content of abstract book, announce each speaker, provide technical support if necessary, and notify each participant about the remaining time. Evaluation criteria of EAP course consisted of three steps: 
- First step was grading for individual aspects of written work, where turnitin similarity results, content, use of source materials, organization, and language are going to be taken into consideration.

- Second step was evaluating material presentation skills, where well presented presentation contains all appropriate sections such as title, abstract, headings in main body, appropriate font, and bibliography. If any of sections is missing it means that presentation needs some developments.

- Third step was commenting on individual work, as well as team work. Learner independence refers to whether student is capable to work autonomously or can complete the project only under pressure of tutor. Team work was evaluated in accordance with how well students coped with the required tasks for organizing a lesson-conference.

\section{Discussion}

Despite all the difficulties the tasks were competed with great enthusiasm. Since all the work was done soundly, students took part in a student conference organized by SDU on April 19, 2019. We were in section \#6 which is called 'Relevant issues of science education theory and methodology in school and university'. There were 18 participants in student conference presenting topics related to their professional sphere. They are Kunsakova Assemzhan with 'The main factors influencing career choice of high school students in Kazakhstan', Rastorguyeva Viktoriya with 'Benefits and drawbacks of implementing English science classes in schools of Kazakhstan', Talasbayeva Zhannur with 'Designing a trilingual magic vocabulary book for the future chemistry and biology teachers', Yerubay Sayazhan with 'No perfume industry in Kazakhstan', Imangali Fatima with 'Preparation necessities of future teachers in the condition of dual education system', Iriskulova Ziyoda with 'Choosing the ideal parenting style in bringing up a well rounded child', Berekekyzy Zhanerke with 'Solving problems with the help of cognitive behavioral therapy', Kabibolla Samal with 'Effectiveness of assessment of students in Nazarbayev Intellectual schools in comparison with ordinary', Bilimkhan Nazerke with 'Effects of available skin creams on our health by its composition', Dilzhanova Assylzhan with 'Inspiring the young generation to be interested in teaching profession', Bolatbekova Aidana with 'The importance of physical exercises for teenagers', Kani Aidana with 'Euthanasia: Right to Die', Abylkayir Dana with 'The impact of modern technology trends on development of education system in Kazakhstan', Sagadinov Sagyndyk with 'The current problems and future perspectives of teaching professions in Kazakhstan', Kanatova Dana with 'How to become the youngest director of school?', Rakhymzhanova Botagoz with 'Feeling the heat: biological impacts of climate change and causes of global warming', Zamirbekkyzy Aiperi with 'The authority of the school teachers and its role in the educational process'.

Thus, admitting the fact that students were freshmen, they dealt with the task perfectly. They showed great interest both in organizing their own fake mini-conference and in participating in the real one. So, Iriskulova Ziyoda was awarded the second place, Kanatova Dana, Yerubay Sayazhan, Beisen Dinara, Rastorguyeva Viktoriya, Kunsakova Assemzhan were nominated as the best speakers, Kani Aidana, Dilzhanova Assylzhan, Kabibolla Samal, Talasbayeva Zhannur were awarded the best report nomination, others were given certificates of participation, and the letter of appreciation was given to the research supervisor for the fact that Iriskulova Ziyoda showed high results and awarded the second place. Moreover, the articles of V. Rastorgueva, Z. Iriskulova, Zh. Talasbayeva, Zh.Berekekyzy, N. Nurdilda, and A. Massuadin were chosen and sent to publish to the university journal [9]. We suppose that very high results were achieved in a very short period of time.

\section{Conclusion}

Students of contemporary world must be supported in mastering both content and competencies. It has to be noted that some changes are required in education only because nowadays' students are the children of the $21^{\text {st }}$ century: age of globalization and integration; age of media and technology; age of big changes in information and communication technologies. Thus, all teachers of Kazakhstan should wonder how Kazakhstani education system responds to these changes and if our educators are doing well in teaching the $21^{\text {st }}$ century skills that students need in order to succeed in learning, living and working. For these reasons, EAP course aims to be based on professionally-oriented competence approach which personalizes today's innovative educational process. Competencies such as critical thinking, problem solving, creativity and innovation, communication, collaboration, personal growth and well-being are combinations of attitudes, skills and knowledge that students develop and apply to demonstrate their career proficiency that could 
successfully be used in the future. So designing the learning process in accordance to students' professional needs is such a breakthrough method that allows students to create their own critical ideas and produce creative products where the main learning goal has become proficiency readiness.

\section{References:}

1. Charles M. \& Pecorari D. Introducing English for Academic Purposes. - London \& New York. : Routledge, 2016. - 206 p.

2. Richards J., and Rodgers T. Approaches and Methods in Language Teaching. - Cambridge.: Cambridge University Press, 2014. - 410 p.

3. Laurence A. Introducing English for Specific Purposes. - UK \& New York.: Routledge, $2018-210$ p.

4. Hutchinson T., and Waters A. English for Specific Purposes: A Learning-Centred Approach. Cambridge.: Cambridge University Press, 1987. - 183 p.

5. Robinson P. English for Specific Purposes (ESP). - Pergamon, 1980.

6. Dudley-Evans, T. and St. John, M. J. Developments in English for Specific Purposes. - Cambridge: Cambridge University Press, 1998.

7. Hyland K. English for Academic Purposes. - New York: Routledge, 2006.

8. http://www.en.m.wikipedia.org

9. Студенттердің, магистранттардың және докторанттардың вылыми конференциясының материалдар жинавыю - Қаскелең, СДУ, 2019. - 179 б.

\section{Г.А.Ризаходжаева ${ }^{l}$ М.М.Акешова}

1,2 Международный казахско-туречкий университет имени Ходжи Ахмета Яссави

\section{К ПРОБЛЕМЕ ФОРМИРОВАНИЯ ПРОФЕССИОНАЛЬНОЙ КУЛЬТУРЫ БУДУЩИХ УЧИТЕЛЕЙ АНГЛИЙСКОГО ЯЗЫКА В УСЛОВИЯХ ИННОВАЦИОННОГО ОБУЧЕНИЯ}

\section{Аннотация}

Цель данной статьи состоит в теоретическом обосновании, разработке и реализации методики формирования профессиональной культуры будущих учителей английского языка в условиях инновационного обучения. Задачи исследования заключаются в том, чтобы раскрыть педагогические предпосылки формирования профессиональной культуры будущих учителей англиского языка в высшей школе, рассмотреть инновационное обучение как форму деятельности в формировании профессиональной культуры будущих учителей и классифицировать эффективные методы и технологии формирования профессиональной культуры будущих учителей англиского языка в условиях инновационного обучения.

Ключевые слова: профессиональная культура, инновационное обучение, будущие учителя английского языка, учебный процесс.

\section{Г.А.Ризаходжсаева ${ }^{1}$ М.М.Акешова}

${ }^{1,2}$ Қожа Ахмет Ясави атындавы Хальққаралық қазақ-түрік университеті

\section{ИННОВАЦИЯЛЫҚ ОҚЫТУ ЖАҒДАЙЫНДА АҒЫЛШЫН ТІЛІ МУҒАЛІМДЕРІНІҢ КӘСІБИ МӘДЕНИЕТІН ҚАЛЫПТАСТЫРУ МӘСЕЛЕСІ}

\section{Анุдатпа}

Бұл мақаланың мақсаты - болашақ ағылшын тілі мұғалімдердің инновациялық білім беру жағдайында кәсіби мәдениетін қалыптастыру әдістемесін теориялық негіздеу, әзірлеу және енгізу. Зерттеудің міндеттері - жоғары білім берудегі болашақ ағылшын тілі мұғалімдерінің кәсіби мәдениетін қалыптастырудың педагогикалық алғышарттарын ашу, инновациялық оқытуды болашақ 